\title{
ПРО ЦИВІЛІЗАЦІЙНИЙ ВИБІР РОЗВИТКУ УКРАЇНИ
}

\author{
О. І. Романюк
}

Романюк О. І. Про цивілізаційний вибір розвитку України. Досліджується проблема цивілізаційних витоків українського суспільства. Проаналізувавши історичні шляхи розвитку України та Росії, автор доводить, що вони належать до різних цивілізаційних ареалів. Україна належить до європейського ареалу, Росія - до євразійського. Основними чинниками, що зумовили цивілізаційні відмінності, виступають відмінності політичних полів, в межах яких відбувався суспільний розвиток.

Ключові слова: цивілізація; цивілізаційний ареал; культура; соціокультурне поле; політичне поле; Україна; Росія.

Романюк А. И. О цивилизационном выборе развития Украины. Исследуется проблема цивилизационных истоков украинского общества. Проанализировав исторические пути развития Украины и России, автор доказывает, что они принадлежат разным цивилизационным ареалам. Украина относится к европейскому ареалу, Россия - к евразийскому. Основными факторами, которые обусловили цивилизационные отличия, выступают различия политических полей, в рамках которых происходило общественное развитие.

Ключевые слова: цивилизация; цивилизационный ареал; культура; социокультурное поле; политическое поле; Украина; Россия.

Romanyuk O. I. On the Civilization Choice of Ukraine's Development. The problem of the Ukrainian society civilization origins is investigated. The author, having analyzed the historical ways of Ukraine and Russia, proves that they belong to different civilization areas. Ukraine belongs to the European area and Russia - to Eurasian one. The main factors that led to the civilization differences are the differences in the political fields, in which social development is going. Russia.

Keywords: civilization; culture; civilization area; culture; socio-cultural field; political field; Ukraine;

Питання про цивілізаційний вибір України відіграє важливу роль у гібридній війні, яку Росія веде проти України. Бажаючи завадити інтеграції України до європейського простору, російська пропаганда стверджує, що це суперечить цивілізаційній сутності українського суспільства, яке належить до євразійської цивілізації. При цьому євразійська цивілізація жорстко протиставляється європейській, до якої сьогодні намагається долучитись Україна. Розібратися в тому, до якого цивілізаційного ареалу тяжіє Україна та чи відповідає інтеграція до Європи цивілізаційній сутності українського суспільства, становить головне завдання цієї статті.

\section{Що являють собою цивілізації та як вони виникають}

Поняття «цивілізація», що походить від латинського слова civilis, що українською перекладається як громадський, суспільний, державний, громадянський, впровадив у науковий обіг для відрізнення соціально організованих спільнот від первісних форм організації людства французький економіст-фізіократ та філософ Віктор де Мірабо* в своїй праці «Друг людства» (1757)․․․ Під впливом Мірабо в науці поширилося трактування цивілізації як стадії суспільного розвитку, якій притаманне виділення соціуму з природи та домінування соціальних чинників життєдіяльності людини над природними. Таке трактування цивілізації використали в своїх працях «Стародавнє суспільство» (1877) Льюїс Морган² та «Походження сім'ї, приватної власності і держави» (1884) Фрідріх Енгельс ${ }^{3}$.

Проте активне студіювання східних суспільств в XIX столітті засвідчило, що вони істотно відрізняються від західних. Це спричинило до розуміння цивілізації не як чогось

* Віктор де Мірабо є батьком більш відомого французького філософа та політичного діяча часів Великої Французької революції Оноре Габріеля де Мірабо.

(C) Романюк, О. I., 2016 
цілісного, а як явища, що складається з декількох ареалів. Французький філософ Шарль Ренув'є в праці «Посібник зі стародавньої філософії» (1844) запропонував поняття локальної цивілізації ${ }^{4}$ Через кілька років французький історик Жозеф Артюр де Гобіно в книзі «Есе про нерівність людських рас» (1853-1855) вирізнив 10 цивілізацій, кожна 3 яких проходить свій власний шлях розвитку ${ }^{5}$. Схожі ідеї одночасно висловив німецький історик Генріх Рюккерт, котрий прийшов до висновку, що історія людства - не єдиний процес, а сума паралельних культурно-історичних процесів, які неможливо розташувати лінійно. Вирізнивши у своєму «Підручнику світової історії в органічному уявленні» (1857) п'ять вищих «культурних типів, він першим звернув увагу на проблему кордонів цивілізацій, їх взаємовпливу, структурних взаємин усередині них ${ }^{6}$. У ХХ столітті вагомий внесок у вивчення локальних цивілізацій зробив англійський історик Арнольд Тойнбі, який у 12-ти томній праці «Розуміння історії» (1934-1961) поділив історію людства на низку локальних цивілізацій, що мають єдину внутрішню схему розвиткуㄱ. Наприкінці XX століття американський політолог Семюел Гантінгтон у праці «Зіткнення цивілізацій та перетворення світового порядку» (1996) проголосив, що після лавинного краху комуністичних режимів на зміну двополярному світові приходить світовий порядок, що грунтується на цивілізаціях. Географічне сусідство цивілізацій часто-густо призводить до конфліктів між ними, які значно загострюються тоді, коли їх кордони є аморфними ${ }^{8}$.

Таким чином, у науці виникло розуміння сутності цивілізації як певного соціокультурного простору (ареалу), якому притаманні спільні риси політичної, правової, економічної, мистецької та технічної культури. У цьому контексті культура, котра трактується як суб'єктивна сфера суспільного життя, що унаочнюється в стереотипах суспільної свідомості, поведінки та діяльності, виступає домінуючим чинником, який відрізняє одні цивілізаційні ареали від інших.

Важливим питанням для реалізації завдання статті $є$ питання про те, як виникають цивілізаційні ареали. Аналіз історичного розвитку привів автора до висновку, що цивілізації постають двома шляхами.

Перший - природний илях, коли формування спільного соціокультурного поля відбувається на грунті спільних історичних витоків, спільної мови, спільної міфології, що сформувалося ще в варварський час. Прикладом цього $є$ давньогрецька цивілізація. Не дивлячись на те, що в стародавній Греції виникло багато полісів (міст-держав), усі вони були залучені до єдиного соціокультурного поля, усвідомлювали свою генетичну близькість, мали спільний пантеон богів та героїв, разом проводили олімпійські ігри (під час яких припинялися усі міжусобні війни), об'єднаними зусиллями відстоювали свою незалежність від перської навали (навали іншої цивілізації).

Другий - імперський шлях, коли спільне соціокультурне поле утворюються внаслідок завоювання чи підкорення одних народів іншими. Яскравим прикладом другого шляху виступає римська цивілізація. Саме внаслідок воєнних завоювань створився Pax Romana, куди поступово були включені досить різні за своїм етнічним складом території. У другому випадку головним чинником формування цивілізації виступає держава, яка нав'язує підкореним народам свою політичну та правову систему, інтегрує їх в свою систему економічних відносин, закріплює за своєю мовою статус мови офіційного спілкування, намагається долучити їх до панівної культури.

Повертаючись до проблеми європейської та євразійської цивілізацій, треба відмітити, що вони виникли різними шляхами: європейська - природнім, євроазійська - імперським.

\section{Генезис та розвиток свропейської цивілізації}

Сучасна європейська цивілізація почала формуватися на грунті культурної спадщини Римської імперії. Варварські держави, що виникли на територіальному просторі Західної Римської імперії, успадкували багато елементів її політичної, правової, економічної, мистецької та технічної культури. Латинська мова стала мовою міждержавного спілкування, а також мовою науки та освіти. Ці держави об'єднувала християнська релігія, яка також була запозичена з Риму. Поступово обшар цього культурного поля розширювався й до нього долучалися території, які раніше не входили до Римської імперії, як от скандинавські та слов'янські. У процесі розвитку європейської цивілізації виникали нові спільні культурні 
елементи: кодекс рицарської честі, родова та державна геральдика тощо. Важливу роль у становленні європейської цивілізації відіграла католицька церква, вселенський характер якої робив ії̈ автономною стосовно держави, що певною мірою обмежувало всевладність останньої. У новий та, особливо, новітній час європейська цивілізація стала тим соціокультурним грунтом, на якому розквітли ідеї гуманізму та лібералізму, сформувалися інституції парламентаризму, конституціоналізму, політичних виборів та виборчого права, відбувся розподіл державної влади на три автономних гілки, виникли системи ринкової економіки та соціального захисту населення.

Розвиток європейської цивілізації не був якимсь абсолютно гармонічним та безконфліктним. У європейській історії було багато внутрішніх міждержавних та громадянських війн. На території Свропи почалися дві світові війни. Проте попри всі складнощі внутрішніх та міждержавних відносин, на європейському просторі поступово набували сили тенденції демократизації та гуманізації суспільних відносин. Якісно нового змісту ці тенденції набули після Другої світової війни, коли розпочався процес економічної та політичної інтеграції європейських країн. Почавшись з утворення спільного ринку вугілля, залізної руди, сталі та чавуну, він через низку проміжних етапів привів до утворення єдиної європейської політико-економічної та правової спільноти (табл. 1).

\section{Таблиця 1}

Етапи формування Європейського співтовариства

\begin{tabular}{|c|l|l|}
\hline Рік & \multicolumn{1}{|c|}{ Підстава } & \multicolumn{1}{|c|}{ Форма інтеграції } \\
\hline 1951 & $\begin{array}{l}\text { Паризький договір про Європейське об’єднання вугілля та } \\
\text { сталі }\end{array}$ & $\begin{array}{l}\text { Європейська спільнота } 3 \\
\text { вугілля та сталі }\end{array}$ \\
\hline 1957 & $\begin{array}{l}\text { Римський договір про усунення перепон щодо вільного пе- } \\
\text { ресування людей, товарів, послуг та капіталу }\end{array}$ & $\begin{array}{l}\text { Європейська економічна } \\
\text { спільнота (Спільний ринок) }\end{array}$ \\
\hline 1979 & $\begin{array}{l}\text { Римський договір про заснування європейського співтова- } \\
\text { риства з атомної енергії }\end{array}$ & $\begin{array}{l}\text { Європейська спільнота } 3 \\
\text { атомної енергії (Свратом) }\end{array}$ \\
\hline 1992 & $\begin{array}{l}\text { Про створення Економічного та Валютного Союзу (ЕВС) } \\
\text { Союзу }\end{array}$ & $\begin{array}{l}\text { Свропейська валютна (моне- } \\
\text { тарна) система }\end{array}$ \\
\hline 1997 & $\begin{array}{l}\text { Лісабонський договір про внесення змін до Договору про } \\
\text { Свропейський союз та Договір про заснування Свропей- } \\
\text { ського співтовариства }\end{array}$ & Європейське співтовариство \\
\hline
\end{tabular}

Разом з розвитком структур та форм інтеграції європейських країн збільшувалося коло iï учасників. 3 6-ти країн, що в 1951 році утворили Європейську спільноту з вугілля та сталі, на сьогоднішній день європейське співтовариство збільшилося до 28 повноправних членів (табл. 2), ще 5 країн (Албанія, Македонія, Сербія, Туреччина, Чорногорія) є кандидатами на вступ до ЄС.

\section{Таблиця 2}

Країни-члени європейського співтовариства

\begin{tabular}{|c|l|}
\hline $\begin{array}{c}\text { Рік } \\
\text { залучення }\end{array}$ & \multicolumn{1}{c|}{ Країни } \\
\hline 1951 & Німеччина, Франція, Італія, Бельгія, Нідерланди, Люксембург \\
\hline 1973 & Велика Британія, Данія, Ірландія \\
\hline 1981 & Греція \\
\hline 1986 & Іспанія, Португалія \\
\hline 1995 & Австрія, Фінляндія, Швеція \\
\hline 2004 & $\begin{array}{l}\text { Естонія, Латвія, Литва, Мальта, Польща, Республіка Кіпр, Словаччина, Словенія, } \\
\text { Угорщина, Чехія }\end{array}$ \\
\hline 2007 & Болгарія, Румунія \\
\hline 2013 & Хорватія \\
\hline
\end{tabular}


Хоча російська пропаганда стверджує, що євроінтеграція суперечить цивілізаційній і історичній сутності слов'янської православної України, але серед країн-членів СС 6 країн (21\% від загальної кількості) мають переважно слов'янське населення, у 5-ти країнах (18\%) провідною релігією є православ'я. Членами ЄС є 11 посткомуністичних країн (39\%), у тому числі 3 - пострадянські (11\%).

Таким чином, якихось соціокультурних та історичних перепон для інтеграції України до європейського співтовариства не існує. Вирішальними чинниками розвитку процесу євроінтеграції є прагнення України долучитися до ЄС та ії відповідність копенгагенським критеріям ${ }^{9}$.

\section{Звідки походить євроазійська цивілізація}

Євразійська цивілізація виникла на грунті російської держави, яка поступово перетворилася на імперію. Хоча офіційна російська історіографія стверджує, що російська державність бере свій початок з Київської Русі, але історичні факти спростовують це твердження. Території, на яких почала формуватися російська державність, дійсно певний час перебували в складі Київської Русі. Проте розвиток процесу феодальної дезінтеграції та наступна монголо-татарська навала, спричинивши загибель давньоруської держави, призвели до того, що корінні західні ії землі та північно-східні креси стали розвиватися в різних політичних полях.

Північно-Східна Русь стала улусом (адміністративно-територіальною одиницею) Золотої Орди - держави, що в 1266 році фактично відокремилася від Монгольської імперії. Початок процесу формування російської державності був покладений у 1328 році, коли московський князь Іван Калита* купив у хана Золотої Орди Узбека ярлик на велике княжіння на руських землях. У структурі Золотої Орди великий князь виконував роль верховного наглядача за руськими землями, що потрапили під монголо-татарську навалу, а його головна функція полягала у вчасному зборі з них данини та ії переправленні до Сараю**. За сприянням ординської влади Іван Калита почав приєднувати до Московського князівства інші землі ${ }^{10}$. Справу Івана Калити продовжили його нащадки. У російській історіографії цей процес одержав назву «собирание русских земель около Москвы». Зміцнившись, Московське князівство почало боротьбу за незалежність від Золотої Орди, що сталося в 1480 році.

Проте, ставши незалежною, Московська держава успадкувала політичну культуру Золотої Орди. Говорячи про історичні витоки російської державності, Карл Маркс у своїй праці «Викриття дипломатичної історії XVIII століття» зазначив: «Колискою Московії було криваве болото монгольського рабства, а не сувора слава епохи норманів. А сучасна Росія $€$ не що інше, як перетворена Московія» ${ }^{11}$. Таку ж думку виказує й доктор історичних наук, професор Казахського національного університету імені Аль-Фарабі Олександр Кадирбаєв: «Саме золотоординська система стала праобразом російської імперської державності. Це проявилося в установленні авторитарної традиції правління, в жорстко централізованій суспільній системі, дисципліни у військовій справі ...» ${ }^{12}$.

Протягом історичного розвитку відбулося декілька спроб європеїзації та модернізації московської (російської) держави.

У другій половині XV століття за Івана III, який одружився на племінниці останнього візантійського імператора Софії Палеолог, з Візантії запозичуються титул «цар»*** та двоглавий орел як державний герб. Створюється ідея спадкування царської влади від візантійських імператорів ${ }^{* * *}$, яка пізніше одержує всебічний розвиток в концепції «Москва - третій Рим» ${ }^{* * * * *}$ і стає важливим елементом державної ідеології. На початку XVIII століт-

* За лінією матері Іван Калита був нащадком хана Батия та, відповідно, Чингізхана

** Столиця Золотої Орди.

*** Від латинського слова caesar, що являло обов'язкову частину титулу римських та візантійських імператорів як наступників Юлія Цезаря.

**** Ця ідея була вперше висловлена митрополитом Зосимою в його праці «Виклад пасхалії» (1492).

***** Основи концепції «Москва третій Рим» були сформульовані в двох посланнях старця псковського Єлізарова монастиря Філофея (кінець 1523 - початок 1524). 
тя Петро I, перетворивши Росію на імперію, провів низку реформ (адміністративну, військову, судову, фінансову) та здійснив зміни в укладі життя й освіті з метою наближення Росії до Європи. Проте ці спроби європеїзації були поверхневими й не призвели до докірних змін соціальних відносин (кріпацтво тільки посилювалося) та характеру політичної влади (вона ставала ще більш жорсткою). У середині XIX століття Олександр II відмінив кріпацтво та провів буржуазні реформи, але самодержавство скасовано не було й збереглося багато інших феодальних пережитків (поміщицьке землеволодіння, станові привілеї тощо). Нарешті, в 1917 році самодержавство та залишки феодалізму були ліквідовані, але владу захопили більшовики, які розбудували першу в історії тоталітарну суспільно-політичну систему, за якої громадянські свободи стали суто декларативними, право на приватну власність було скасоване, політичні репресії набули небувалого розмаху, централізація влади досягла абсолютного максимуму та збереглися імперські амбіції держави, хоча вона одержала нову (ідеологічну) назву - СРСР. Загибель комуністичного режиму та розпад СРСР, що сталися в 1991 році, здавалося, давали надію Росії вирватися зі зачарованого кола євразійського цивілізаційного розвитку. Однак завдяки політичній культурі, сформованої протягом усього цього розвитку, через десять років до влади прийшов вихованець радянських спецслужб Володимир Путін, за якого почався процес ретоталітаризації Росії ${ }^{13}$ та робляться спроби воєнним шляхом відродити російську імперію ${ }^{14}$.

Аналізуючи історію російської державності, відомий російський історик і політолог Юрій Півоваров зауважив, що усі перетворення, які відбувалися Росії, являли собою «рух 3 пункту А до пункту ... А ${ }^{15}$. Тобто відбувалася певна зміна політичної форми без зміни суспільно-політичної якості, що залишалася деспотичною.

\section{Цивілізаційні шляхи України}

На відміну від Росії, Україна з часів Київської Русі була щільно пов'язана $з$ європейським цивілізаційним простором. Про це, зокрема, свідчать династичні зв'язки київських князів. Особливо яскравий приклад у цьому плані демонструють шлюби дітей Ярослава Мудрого. Його сини були одружені: Ізяслав - 3 дочкою польського князя Мешка II, Святослав - $з$ онукою цісаря Священної Римської імперії Генріха II, Всеволод - 3 дочкою Візантійського імператора Костянтина Мономаха, Володимир та Ігор - 3 дочками німецьких графів. Його дочки були замужем: Слисавета за королем Норвегії Гаральдом III Суворим, а потім за королем Данії Свейном II, Анастасія - за королем Угорщини Андрашем II, Агата - за англійським королем Едвардом Вигнанцем, Анна - за королем Франції Генріхом I.

Після дезінтеграції Київської Русі, внаслідок об'єднання Волинського та Галицького князівств, виникла велика держава, яка увійшла в історію як Галицько-Волинська Русь. Ïї територія в період розквіту простягалася від Городка (Гродно) на півночі до Родні на півдні та від Сяноку (Саноку) на Заході до Переяслава на Сході. У 1230 році до ііі складу увійшло Київське князівство $з$ містом Київ. Галицько-Волинська Русь чинила впертий опір монголо-татарські навалі і хоча була вимушена визнати сюзеренітет золотоординських ханів, фактично залишилася незалежною державою. У 1253 році папа римський Інокентій IV надав Данилі Галицькому титул короля, що засвідчило про прийняття цієї проукраїнської держави в сім'ю європейських народів. У європейських хроніках того часу ця держава згадувалася як Regnum Russiæ, тобто Руське королівство. Відповідно до європейської політичної культури ця держава одержала герб - золотий лев, що спинається на скелю, на синьому тлі. Барви гербу Руського королівства в XIX столітті стали кольорами національного прапору України.

На жаль, ця держава не змогла усталитися. Після смерті в 1340 році короля Юрія II почалися міжусобні чвари, які закінчилися поділом Галицько-Волинської Русі між Польщею, яка захопила Галичину, та Литвою, якій відійшла Волинь, Поділля, Чернігово-Сіверщина, Брацлавщина, Київщина та Переяславщина. Проте внаслідок цього більшість території сучасної України потрапили до складу держав, що вже були інтегровані до європейського політичного простору. У 1569 році на підставі Люблінської унії Польща й Литва об'єдналися в єдину державу - Річ Посполиту. За своїм політичним устроєм Річ Посполита являла собою децентралізовану державу, в якій розквітла «шляхетська демократія» як одна з первинних форм представницької демократії, за якої шляхта мала широкі політичні 
права. У країні діяв двопалатний сейм. Верхня палата (сенат) включала представників вищого духовенства та магнатів, зайнятих на високих державних посадах. До нижньої палати (посольської ізби) входили депутати, обрані на сеймиках (з'їздах місцевої шляхти). Сейму належало право обрання короля, котрий був зобов'язаний кожні два роки скликати сейм, не міг без його згоди оголошувати війну, укладати мир, видавати закони, скликати ополчення. Відмова монарха від виконання своїх зобов'язань звільняла шляхту від покори йому $^{16}$. Під час перебування в складі Речі Посполитої в Україні було запроваджене Магдебурзьке право, що сприяло розвиткові місцевого самоврядування, виникли перші університети (у 1659 році - Києво-Могилянська академія, у 1661 році Львівський університет). Під час перебування у складі Речі Посполитої в Україні виникла греко-католицька церква, в межах якої була зроблена спроба об'єднати православ'я і католицизм*.

Ситуація починає докорінно змінюватися, коли в ході Визвольної війни під керівництвом Богдана Хмельницького 1654 року відбулося підписання Переяславської угоди, яка українською стороною мислилася як угода про воєнно-політичний союз України та Московії для виходу з-під польської залежності. За нею Україна визнавала протекторат московського царя, але мала зберегти свої державні права. 3 цієї події починається новий етап в історії України, коли іiї територія починає поступово включатися до складу Російської імперії, а потім Радянського Союзу та, відповідно, потрапляє у поле впливу євразійської цивілізації (табл. 3).

\section{Таблиця 3}

Включення сучасних українських земель до складу Російської імперії та Радянського Союзу

\begin{tabular}{|c|c|c|}
\hline $\begin{array}{c}\text { Рік } \\
\text { входження }\end{array}$ & Підстава & Землі \\
\hline 1667 & $\begin{array}{l}\text { Андрусівське сепаратне перемир'я між } \\
\text { Московським царством і Річчю Посполи- } \\
\text { тою від } 30 \text { січня } 1667 \text { р. }\end{array}$ & $\begin{array}{l}\text { Лівобережна Україна, Сіверська земля з } \\
\text { Черніговом і Стародубом та Київ (пер- } \\
\text { вісно передбачалося, що на } 2 \text { роки) }\end{array}$ \\
\hline 1783 & $\begin{array}{l}\text { Маніфест Катерини II від } 8 \text { квітня 1783-го } \\
\text { «Про прийняття півострова Кримського, } \\
\text { острова Тамані і всієї Кубанської сторони } \\
\text { під Російську державу» }\end{array}$ & $\begin{array}{l}\text { Крим (у } 1954 \text { році був включений до } \\
\text { складу УРСР на правах області). У лю- } \\
\text { тому } 2014 \text { року окупований Російською } \\
\text { Федерацією }\end{array}$ \\
\hline 1793 & $\begin{array}{l}\text { Другий поділ Річчі Посполитої, затвердже- } \\
\text { ного сеймом у Гродні }\end{array}$ & $\begin{array}{l}\text { Київщина, Східна Волинь, Поділля та } \\
\text { Брацлавщина }\end{array}$ \\
\hline 1795 & Третій поділ Річчі Посполитої & $\begin{array}{l}\text { Західна Волинь (в період 1921-1939 ро- } \\
\text { ків на підстав Ризького мирного догово- } \\
\text { ру входила до складу Польщі) }\end{array}$ \\
\hline 1939 & $\begin{array}{l}\text { Радянська воєнна агресія проти Польщі } \\
\text { вересня 1939-го на підставі пакту Молото- } \\
\text { ва-Ріббентропа }\end{array}$ & Галичина та Західна Волинь \\
\hline 1940 & $\begin{array}{l}\text { Ультиматум радянського уряду Румунії від } \\
26 \text { червня } 1940 \text { р. }\end{array}$ & $\begin{array}{l}\text { Північна Буковина та Південні райони } \\
\text { Бессарабії }\end{array}$ \\
\hline 1945 & $\begin{array}{l}\text { Радянсько-чехословацький договір про За- } \\
\text { карпатську Україну від } 24 \text { червня } 1945 \text { р. }\end{array}$ & Закарпаття \\
\hline
\end{tabular}

Оцінюючи роль Переяслава в історії України, Юрій Шевельов наголосив, що «він став початком великої трагедії народу» ${ }^{17}$ та «передумовою української культурної інвазії» ${ }^{18}$. За час перебування України в складі євразійської імперії ії соціокультурне поле було суттєво деформоване, на що вплинули три чинники.

По-перше, деспотичний характер влади. Включення українських земель до російської держави супроводжувалося ліквідацією автономії місцевої влади та репресіями проти діячів, котрі не погоджувалися з цим; руйнуванням Запорізької Січі; скасуванням магде-

\footnotetext{
* Створена внаслідок Берестейської унії 1596 року.
} 
бурзького права; ще більшим закріпаченням населення; забороною української мови та літератури. Українську мову було оголошено «малороссйским наречием» - зіпсованого поляками варіантом російської мови.

Загибель царату та встановлення більшовицького режиму докорінно не змінили сутність влади. Вона стала ще більш деспотичною - тоталітарною та залишалася імперською. Хоча за більшовицького режиму Україну було проголошено державним утворенням (Українською Радянською Соціалістичною Республікою) у складі СРСР, але ця державність була суто декораційною та декларативною. Україна й надалі жорстко управлялася 3 імперського центру. Скасування культурних утисків та обмежень, що мало місце в першій період радянської доби, невдовзі змінилося широкомасштабними репресіями проти української інтелігенції. За підрахунками академіка Миколи Жулинського, у 1930 році друкувалися твори 259 українських письменників, після 1938-го з них публікувалося тільки 36. 3223 -х зниклих українських письменників 17 було розстріляно, 8 кінчили життя через самогубство, 175 було заарештовано і вислано - їх доля невідома, 16 пропало невідомо куди, і тільки 7 померло своєю смертю ${ }^{19}$. Проте злочини більшовицького режиму не обмежилися репресіями проти української інтелігенції. За радянських часів Україна зазнала три штучних голодомора $\left(1921-1923,1932-1933\right.$ та 1946-1947 років) ${ }^{20}$. Особливо жахливим був голодомор 1932-1933 років, наслідком якого стало знищення, за різними підрахунками, від 8 до 11 мільйонів населення України ${ }^{21}$. За своїми масштабами і наслідками його можна порівняти тільки з голокостом євреїв за нацистського режиму.

Велику роль у денаціоналізації України відіграла російська (московська) православна церква*, яка за Петра I була остаточно перетворена на одну зі структур державної влади. Включення українських земель до складу Росії супроводжувалося забороною греко-католицької церкви та переведенням православних парафій з Константинопольського патріархату до Московського. Богослужіння українською мовою та українські церковні книги були заборонені. Головною функцією церкви стало виховання в населення покори імперській владі. На початку комуністичної доби ця церква була фактично знищена, проте в роки Другої світової війни ії було реанімовано та поставлено під суворий нагляд органів державної безпеки.

По-друге, різний час перебування різних земель України у складі євразійської імперії. Різні землі України перебували там від 324 до 46 років. Різний час перебування зумовив відмінні наслідки. Населення Східної України є більш зденаціоналізованим, у його свідомості більш вкорінені тоталітарні стереотипи мислення та проросійські зовнішньополітичні орієнтації. Населення ж Західної України, а особливо тієї ії частини, яка після поділу Речі Посполитої потрапила до складу ліберальної австрійської монархії, у переважній своїй більшості зберегло національні культуру, мову та традиції; у його свідомості значно більше поширення мають ліберально-демократичні цінності та панують європейські зовнішньополітичні орієнтації.

По-третє, міграція російського населення. За роки перебування України в складі Російської імперії та СРСР на ії теренах осіла значна кількість російського населення. Тільки в період з 1897-го до 1991-го питома вага етнічних росіян серед населення України збільшилася 3 8,8\% до 22,1\%22. Це принесло з собою відповідні стереотипи свідомості та поведінки, що не могло не позначитися на суспільній культурі. Оскільки більшість росіян осідала на Сході України, то це стало ще одним чинником формування регіональних культурних відмінностей.

Проте, не дивлячись на істотні деформації, цивілізаційний код українського суспільства знищено не було. Внаслідок цього більшість українців на рівні підсвідомості завжди відчувала свою окремість від російської держави та євразійської цивілізації. У періоди буремних подій у Росії, пов'язаних з розвалом імперської влади, робилися спроби фундації суверенної української держави. Після загибелі царату було проголошено створення Укра-

* Виникла у 1448 році, самочинно від’єднавшись від Константинопольського патріархату. Проте іiі автокефалія ще 141 рік не визнавалася в християнському світі. Тільки в 1589 році, коли Борис Годунов підступом заманив Константинопольського Патріарха Ієремію II до Москви та фактично ув'язнив його, той після піврічного утримання в неволі погодився надати московському митрополиту титул Патріарха. 
їнської Народної Республіки, яка проіснувала більше трьох років (1917-1920), але впала під натиском агресії більшовицької Росії. В умовах тяжкої кризи комуністичного режиму, після провалу путчу ДКНС 24 серпня 1991 року Верховна Рада України абсолютною більшістю голосів депутатів ухвалила «Акт проголошення незалежності України» ${ }^{* *}$ та винесла його на загальноукраїнський референдум ${ }^{23} .1$ грудня 1991 року 90,32\% мешканців України (28.804.071 особа), що взяли участь у референдумі***24, підтвердили цей Акт. Проти проголосувало лише $7,8 \%$ учасників. $2,1 \%$ бюлетенів було визнано недійсними. Причому в усіх без винятку регіонах України абсолютна більшість населення підтримала незалежність (від 54,19\% у Автономній Республіці Крим до 98,67\% у Тернопільській області) ${ }^{25}$. Вихід України зі складу Радянського Союзу призвів до остаточного розвалу цього імперського утворення, яке припинило своє існування 26 грудня 1991 року.

Здобуття незалежності вивело Україну з політичного поля Росії, а отже створило умови для її повернення до європейського простору. У вересні 1993 року в Україні було відкрито представництво Європейської Комісії (після набуття чинності Лісабонським договором це представництво перетворилося на представництво Європейського Союзу в Україні). 16 червня 1994 року було підписано «Угоду про партнерство і співробітництво між Україною і Свропейськими Співтовариствами та їх державами-членами» (набула чинності 1 березня 1998 року після погодження з усіма державами-членами ЄС), яка започаткувала співробітництво 3 широкого кола політичних, торговельно-економічних та гуманітарних питань ${ }^{26}$.

Проте шлях України до європейської цивілізації виявився не таким і легким. Його гальмування зумовлювали: труднощі трансформаційного періоду, що народжували ностальгію за попереднім «стабільним» життям»; велика питома вага етнічних росіян, котрі переживали розрив з історичною батьківщиною; вплив Росії, яка намагалася зберегти Україну в своєму геополітичному полі. Кульмінаційними в русі України до Європи стали події, пов'язані з відмовою під тиском Росії режиму Януковича підписати угоду про асоціацію України з СС. Відмова стала приводом «європейської революції» в Україні (21 листопада 2013 - 27 лютого 2014), яка усунула проросійський режим Януковича ${ }^{27}$. Після революції нова українська влада, підписавши та ратифікувавши угоду про асоціацію з $\mathrm{CC}^{28}$, визначила чіткий курс країни на євроінтеграцію. Відповіддю Росії на «європейську революцію» стала агресія проти України. Росія, порушуючи міжнародне право та усі двосторонні й багатосторонні договори, окупувала український Крим, інспірувала заколот сепаратистських сил на Донбасі та надала їм пряму військову підтримку.

У контексті завдання цієї статті маємо відмітити два основних наслідки російської агресії. По-перше, вона яскраво унаочнила сутність євразійської цивілізації, генетичні коріння якої сходять до ординського часу. Відомий російський політолог Лілія Шевцова 3 цього приводу зауважує: «Україна змусила Російську систему скинути маску європейськості, і світ побачив огидний оскал ...» ${ }^{29}$. По-друге, російська агресія призвела до значного посилення антиросійських настроїв та, одночасно, євроінтеграційних орієнтацій в українському суспільстві. За результатами репрезентативного соціологічного опитування, проведеного Центром ім. Олександра Разумкова в квітні 2015 року, 63,7\% респондентів виказали негативне ставлення до Росії, а 75,5\% - до Путіна. Позитивне ставлення українців до росіян за рік впало $344,9 \%$ до 28,9\%. Разом з тим $52 \%$ українців вважають, що Україна повинна приєднатися до ЄС, $43,3 \%$ - до НАТО. Рік тому вступ до ЄС підтримувало тільки 43,3\% населення України, до НАТО - 36,7\% ${ }^{30}$.

\footnotetext{
* Українську Народну Республіку (УНР) було проголошено 7 листопада 1917 року (після більшовицького жовтневого перевороту в Росіі) спочатку як автономну республіку у складі Російської республіки. Після початку більшовицької агресії проти України, 22 січня 1918 року УНР було проголошено незалежною державою. У період з 29 квітня по 14 грудня 1918 року, внаслідок гетьманського перевороту, назву УНР було замінено на Українську Державу. Після антигетьманського повстання назву УНР було відновлено.

*** 3450 депутатів Верховної Ради України 392 депутати підтримали цей акт, 4 проголосували «проти».

**** У референдумі взяло участь 31.891 .742 громадянина, або 84,18\% від загальної кількості внесених до списків.
} 


\section{Висновки}

Європейська та євразійська цивілізації являють два різни типи цивілізаційних ареалів. Європейська цивілізація являє собою циивілізацію вільних народів, яка сформувалася природним шляхом. Натомість євроазійська цивілізація - це держава-циивілізація, що виникла внаслідок насильницького залучення різних народів до імперського політичного поля. Типологічна відмінність зумовила різні моделі цивілізаційного розвитку. Свропейській цивілізації притаманна поступова еволюиійна модель, євразійській - ииклічна. У межах різних типів панують відмінні методи поширення соціокультурного поля. У межах цивілізації народів воно поширюється на грунті добровільного сприйняття культурних цінностей, у межах держави-цивілізації - через їх силове нав’язування політичною владою.

Генетично Україна більш пов'язана з європейською цивілізацією, з якою вона мала тісний зв'язок протягом багатьох століть. Перебування українських земель у політичному та соціокультурному полі євразійської цивілізації тривало значно менший термін. Входження українських земель до складу російської держави негативно позначилося на розвитку національної культури, який істотно загальмувався. Відбулася деформація цивілізаційних основ українського суспільства. Оскільки різні регіони України перебували в складі російської імперії та її наступнику СРСР різний час, то ступінь деформації в різних регіонах $\epsilon$ різним. Проте ці деформації не змогли знищити європейські коріння українського етносу. Усвідомлення українців себе як окремої від росіян спільноти великою мірою було спричинене генетичною несумісністю європейської та євразійської цивілізацій. Це усвідомлення народжувало прагнення до державної незалежності України, що було реалізоване в 1991 році. Здобуття Україною державної незалежності відкрило перед нею можливості реінтеграції до Європи. Хоча рух на шляху до європейського співтовариства гальмують ментальні нашарування минулої доби та тиск з боку Росії, але переважна більшість українського суспільства налаштована проєвропейські, що вселяє надію на успішне його завершення.

Таким чином, хоча Україна певний час перебувала в євразійському політичному та соціокультурному просторі, проте українське суспільство зберегло своє історичне коріння, щільно переплетене з європейським. Тому сучасне євроінтеграційне устремління України $\epsilon$ не чимсь протиприродним, що суперечить цивілізаційній сутності українського суспільства, а намаганням його повернення до своїх цивілізаційних витоків.

${ }^{1}$ Riqueti de Mirabeau V. L'Ami des hommes, ou Traité de la Population, - Hambourg: Chretien Hérold, 1756-1762. - Les 6 vol.

${ }^{2}$ Morgan L. H. Ancient Society or Researches in the Lines of Human Progress from Savagery. Through Barbarism to Civilization. - Henry Holt \&Co, $1877-560$ p.

${ }^{3}$ Енгельс Ф. Походження сім'ї, приватної власності і держави // К. Маркс, Ф. Енгельс. Вибрані твори в трьох томах / Пер. з нім. - К.: Політвидав України, 1977. - Т. 3. - С. 190-336.

${ }^{4}$ Renouvier Ch. B. Manuel de philosophie ancienne. - Paris: Paulin, 1844. - Vol. 1. - P. 24-26.

${ }^{5}$ Гобино Ж. А. де. Опыт о неравенстве человеческих рас / пер с франц. - М.: Одиссей, Олмапресс, 2000. - 765 c.

${ }^{6}$ Rückert H. Lehrbuch der Weltgeschichte in organischer Darstellung. - Leipzig: Weigel, 1857. - $616 \mathrm{~s}$.

${ }^{7}$ Тойнби А. Дж. Постижение истории: сборник / Сост. А. П. Огурцов; пер с англ. М.: Прогресс, 1991. $-736 \mathrm{c}$.

${ }^{8}$ Хантингтон С. Столкновение цивилизаций и преобразование мирового порядка / Пер. с англ. - М.: ООО «Изд-во АТС», 2003. - 603 с.

${ }^{9}$ Критерії щодо умов вступу до Європейського Союзу, ухвалені Європейською Радою на своєму засіданні в Копенгагені в червні 1993 року. Вимагають від країни, що намагається вступити до ЄС, стабільності установ, які гарантують демократію, верховенство права, дотримання прав людини та захист прав меншин; наявність ефективної ринкової економіки; прийняття правил співтовариства. Див.: Presidency Conclusions Copenhagen European Council - 21-22 June 1993. - URL: http://www. europarl.europa.eu/enlargement/ec/pdf/cop_en.pdf (дата звернення 10.10.2015).

${ }^{10}$ Костеиьька М. Колаборант Іван Калита // Історія плюс. - 2015 (березень). - № 3 (16). - С. 20-21.

${ }^{11}$ Маркс K. Разоблачения дипломатической истории XVIII века. - URL: http://rko.marsho.net/ $\mathrm{articl} / \mathrm{marx} . \mathrm{htm}$ (дата звернення 21.09.2015).

${ }^{12}$ Кадырбаев А. Ш. Золотая Орда как предтеча Российской империи. - URL: http://www.ca-c.org/ datarus/kadirbaev.shtml (дата звернення 21.09.2015). 
13 Романюк О. I. Про характер сучасного політичного режиму Росії // Вісник Національного університету «Юридична академія України ім. Я. Мудрого». Серія: філософія, філософія права, політологія, соціологія. - Харків, 2014. - № 4. - С. 152-159.

14 Романюк О. I. Російсько-український воєнно-політичний конфлікт : причини та шляхи розв'язання // Вісник Національного університету «Юридична академія України ім. Я. Мудрого». Серія: філософія, філософія права, політологія, соціологія. - Харків, 2015. - № 3 - С. 244-248.

${ }^{15}$ Пивоваров Ю. С. Русская власть и публичная политика. (Заметки историка о причинах неудачи демократического транзита) // Полис. - 2006. - № 1. - С. 13.

16 Шляхетська демократія. - URL: https://uk.wikipedia.org/wiki/Шляхетська_демократія (дата звернення 28.09.2015).

17 Шевельов Ю. 3 історії незакінченої війни / Упор. О. Забужко, Л. Масенко. - Київ: Вид. дім «Києво-Могилянська академія», 2009. - С. 70.

18 Там само. - С. 64.

19 Жулинский М. Художник, распятый на кресте политики. Судьба Владимира Винниченко // Дружба народов. - 1989. - № 12. - С. 147.

${ }^{20}$ Веселова О. М. Голодомори в Україні, 1921-1923, 1932-1933, 1946-1947: Злочини проти народу / О. М. Веселова, В. І. Марочко, О. М. Мовчан. - 2-е вид., допов. - Київ, Нью-Йорк: Вид-во М. П. Коць, 2000. - 174 с.

${ }^{21}$ Кравчук Л. М. Ми не маємо права знехтувати уроками минулого. Виступ на науковій конференції, присвяченої 60-м роковинам голодомору 1932-1933 pp. // Голос України. - 1993. - 11 вересня.

${ }^{22}$ Чорний C. Національний склад населення України в XX сторіччі. - Київ: Картографія, 2001. $-86 \mathrm{c}$.

${ }^{23}$ Про проголошення незалежності України: постанова Верховної Ради Української РСР від 24 серпня 1991 р. № 1427 // Відомості Верховної Ради України. - 1991. - № 38. - С. 502.

${ }^{24}$ У референдумі взяло участь 31.891 .742 громадянина, або 84,18\% від загальної кількості внесених до списків.

${ }^{25}$ Відомість про результати Всеукраїнського референдуму, 1 грудня 1991 р. // ЦДАВО України. URL: http://www.archives.gov.ua/Sections/15r-V_Ref/index.php?11 (дата звернення 05.10.2015).

${ }^{26}$ Угода про партнерство і співробітництво між Україною і Європейськими Співтовариствами та їх державами-членами - URL: http://zakon5.rada.gov.ua/laws/show/998_012 (дата звернення 12.10.2015).

${ }^{27}$ Романюк О. I. Друга посткомуністична революція в Україні // Вісник Харківського національного університету ім. В. Н. Каразіна. - № 111: Зб. наук. пр. - Серія: «Питання політології». - Харків, 2014. - Вип. 26. - С. 14-22.

${ }^{28}$ Угода про асоціацію між Україною, з однієї сторони, та Європейським Союзом, Свропейським співтовариством з атомної енергії і їхніми державами-членами, з іншої сторони (ратифікована Законом України № 1678-VII від 16.09.2014) - URL: http://zakon0.rada.gov.ua/laws/show/984 011 (дата звернення 12.10.2015).

${ }^{29}$ Политолог РФ рассказала о катастрофической политике Путина в отношениях с Украиной URL: http://www.facenews.ua/news/2015/293654/ (дата звернення 11.10.2015).

${ }^{30}$ Більше половини українців підтримують вступ до ЄС і лиш $12 \%$ - до Митного союзу - URL: http://www.pravda.com.ua/news/2015/04/23/7065596/ (дата звернення 12.10.2015). 